\title{
ANALISIS HARGA KEBUTUHAN POKOK DAMPAK COVID-19 PERSPEKTIF IMAM YAHYA BIN UMAR
}

\author{
Chiska Nova Harsela ${ }^{1}$, Fa'iqotul Fauziyah ${ }^{2}$
}

Green Publisher, IAIN Syekh Nurjati Cirebon

Email: chiska026@gmail.com, faiqotulfauziyah51@gmail.com

Abstrak
Unit Simpan Pinjam merupakan unit usaha yang paling besar menyerap modal usaha
koperasi. Namun permasalahan yang terjadi yaitu pada penyusunan laporan keuangan
koperasi masih terdapat kekurangan dan ketidaksesuaian dengan pedoman yang telah dibuat
oleh Pemerintah yaitu Peraturan Menteri Koperasi dan UMKM No.13/Per/M.KUKM/IX/2015 tentang pedoman akuntansi usaha simpan pinjam koperasi. Penelitian ini bertujuan agar kita dapat memahami penyebab yang memicu terjadinya kenaikan harga bahan pokok di pasaran semenjak terjadinya pandemi covid19 dengan merujuk pada persepektif Imam Yahya Bin Umar sebagai ahli ekonomi islam yang pemikirannya berfokus pada sistem pasar. Penelitian ini menggunakan metode kualitatif dengan mencari dari beberapa referensi dan literature review yang mendukung materi kajian ilmiah, Hasil dari penelitian ini ialah : Dalam rangka memitigasi dampak COVID-19 pada perekonomian dan mencegah terjadinya kenaikan harga pada kebutuhan pokok atau terjadinya inflasi, Pemerintah telah mengumuman stimulus fiskal jilid I, II, dan III. Laporan keuangan yang telah disajikan oleh KPPP JABAR yaitu Neraca dan PHU keseluruhan telah disajikan cukup baik. Laporan keuangan KPPP JABAR yang sudah disajikan masih belum sesuai dengan komponen laporan keuangan menurut pedoman akuntansi simpan pinjam. Kesesuaian Laporan Keuangan Koperasi terhadap Permen No. 13 tahun 2015 jika dalam bentuk persentase sebesar $18,42 \%$.

Kata kunci: Yahya bin Umar, Regulasi Harga, Dampak, Covid-19

\begin{abstract}
Savings and Loans Unit is a business unit that absorbs the largest cooperative business capital. However, the problem that occurs is that in the preparation of cooperative financial statements, there are still deficiencies and discrepancies with the guidelines that have been made by the Government, namely the Regulation of the Minister of Cooperatives and MSMEs No.13/Per/M.KUKM/IX/2015 concerning accounting guidelines for cooperative savings and loans. This study aims so that we can understand the causes that have triggered the increase in the price of basic commodities in the market since the COVID-19 pandemic by referring to the perspective of Imam Yahya Bin Umar as an Islamic economist whose thoughts focus on the market system.This study uses a qualitative method by looking for references and literature reviews that support scientific study material. The results of this study are: In order to mitigate the impact of COVID-19 on the economy and prevent price increases for basic necessities or inflation, the Government has announced a stimulus fiscal volumes I, II, and III. The financial reports that have been presented by KPPP JABAR, namely the balance sheet and PHU have been presented quite well. The financial statements of KPPP JABAR that have been presented are still not in accordance with the components of the financial statements according to the savings and loan accounting guidelines.The Conformity of Cooperative Financial Statements with Ministerial Regulation No. 13 of 2015 if in the form of a percentage of $18.42 \%$.

Keywords: Yahya bin Umar, Price Regulation, Impact, Covid-19
\end{abstract}

Diterima: 26-11-2020; Direvisi: 6-12-2020; Disetujui: 6-12-2020:

\begin{tabular}{ll}
\hline & $\begin{array}{l}\text { Chiska Nova Harsela, Fa'iqotul Fauziyah. (2020). Analisis Harga Kebutuhan Pokok Dampak } \\
\text { Covid-19 Perspektif Imam Yahya Bin Umar. Co-Value: Jurnal Ekonomi, Koperasi } \\
\text { Kow to cite: }\end{array}$ \\
\hline E-ISSN: & Kewirausahaan Vol 11(3): 110-117 \\
\hline Published by: & https://greenpublisher.id/
\end{tabular}




\section{PENDAHULUAN}

Pandemi virus COVID-19 atau yang umum disebut virus Korona di masyarakat kian hari semakin menjangkiti perekonomian Indonesia. Dampak ekonomi akibat virus ini semula hanya menggerus sisi eksternal perekonomian Indonesia melalui kenaikan sejumlah komoditas impor dari China. Namun, seiring penyebaran virus yang sangat cepat. [Sampai dengan 23 Maret 2020, sebanyak 579 orang di Indonesia positif Korona, sembuh 30 orang, dan 49 meninggal dunia (Pusat Informasi COVID-19, 2020)], stabilitas perekonomian pun terkena dampak.

Nilai tukar rupiah terus melemah tajam, sementara pasar bursa pun meradang seiring laju Indeks Harga Saham Gabungan (IHSG) yang terkoreksi dalam. Pertumbuhan ekonomi pun diperkirakan akan melambat drastis, terkikis oleh penjalaran dampak virus ke berbagai sektor di perekonomian. Merebaknya pandemi COVID-19 turut berimplikasi terhadap lonjakan permintaan akan bahan kebutuhan pokok. Anjuran pemerintah agar masyarakat melakukan kegiatan bekerja, belajar dan beribadah dari rumah mendorong masyarakat untuk melakukan pembelian sembako secara masif guna memenuhi persediaan hingga beberapa waktu mendatang.

Berdasarkan Pusat Informasi Harga Pangan Strategis Nasional (PIHPS) per 23 Maret 2020, beberapa komoditas bahan pokok mengalami kenaikan harga (rata-rata harga nasional) yang signifikan dalam sebulan terakhir dan kenaikan sejak awal tahun (year to date/ytd) antara lain gula pasir lokal 18,71\% (ytd 31,2\%), gula pasir kualitas premium $10,68 \%$ (ytd 15,54\%), bawang putih naik 36\% (ytd), bawang merah 5,56\% (ytd 4,57\%), cabai rawit merah $18,11 \%$ (ytd 2,74\%). Sementara itu, harga kebutuhan pokok lainnya seperti beras, daging ayam, daging sapi, telur ayam, dan minyak goreng relatif stabil.

Fenomena panic buying yang sempat terjadi di beberapa daerah red zone persebaran Covid-19 berdampak pada keterbatasan akses kelompok rumah tangga kelas menengah ke bawah yang tidak mampu "menyetok" bahan makanan. Untuk meredam shock kenaikan permintaan, potensi penimbunan kebutuhan pokok, dan kenaikan hargaharga atau bahkan inflasi yang berujung pada krisis, pemerintah harus segera melakukan sesuatu dengan mengeluarkan solusi kebijakan yang tepat.

Berkaca dari permasalahan diatas, penulis tertarik untuk menganalisis permasalahan tersebut berdasarkan perspektif pemikiran seorang pakar ekonomi islam yakni Imam Yahya Bin Umar. Beliau adalah salah seorang fuqaha mazhab Maliki. Ulamanya yang bernama lengkap Abu Bakar Yahya bin Umar bin Yusuf Al-Kannani AlAndalusi ini lahir pada tahun $213 \mathrm{H}$ dan dibesarkan di Kordova, Spanyol. Seperti para cendekiawan Muslim terdahulu, ia berkelana ke berbagai negeri untuk menuntut ilmu. Kiprahnya dalam dunia pemikiran ekonomi pun cukup luas. Oleh karena itu penulis tertarik untuk mengkaji lebih dalam pemikiran-pemikiran beliau terutama mengenai pandangannya tentang kenaikan harga.

\section{METODE PENELITIAN}

Dalam penulisan artikel ini, penulis menggunakan metode kualitatif dengan mencari dari beberapa referensi dan literature review yang mendukung materi kajian ilmiah "analisis harga kebutuhan pokok dampak covid-19 perspektif Imam Yahya Bin Umar". 


\section{HASIL DAN PEMBAHASAN}

\section{Dampak Covid-19 Terhadap Harga Kebutuhan Pokok}

Pandemi virus COVID-19 atau yang umum disebut virus Korona di masyarakat kian hari semakin menjangkiti perekonomian Indonesia. Dampak ekonomi akibat virus ini semula hanya menggerus sisi eksternal perekonomian Indonesia melalui kenaikan sejumlah komoditas impor dari China. Namun, seiring penyebaran virus yang sangat cepat. [Sampai dengan 23 Maret 2020, sebanyak 579 orang di Indonesia positif Korona, sembuh 30 orang, dan 49 meninggal dunia (Pusat Informasi COVID-19, 2020)], stabilitas perekonomian pun terkena dampak.

Nilai tukar rupiah terus melemah tajam, sementara pasar bursa pun meradang seiring laju Indeks Harga Saham Gabungan (IHSG) yang terkoreksi dalam. Pertumbuhan ekonomi pun diperkirakan akan melambat drastis, terkikis oleh penjalaran dampak virus ke berbagai sektor di perekonomian. Merebaknya pandemi COVID-19 turut berimplikasi terhadap lonjakan permintaan akan bahan kebutuhan pokok. Anjuran pemerintah agar masyarakat melakukan kegiatan bekerja, belajar dan beribadah dari rumah mendorong masyarakat untuk melakukan pembelian sembako secara masif guna memenuhi persediaan hingga beberapa waktu mendatang.

Berdasarkan Pusat Informasi Harga Pangan Strategis Nasional (PIHPS) per 23 Maret 2020, beberapa komoditas bahan pokok mengalami kenaikan harga (rata-rata harga nasional) yang signifikan dalam sebulan terakhir dan kenaikan sejak awal tahun (year to date/ytd) antara lain gula pasir lokal 18,71\% (ytd 31,2\%), gula pasir kualitas premium $10,68 \%$ (ytd 15,54\%), bawang putih naik 36\% (ytd), bawang merah 5,56\% (ytd 4,57\%), cabai rawit merah $18,11 \%$ (ytd 2,74\%). Sementara itu, harga kebutuhan pokok lainnya seperti beras, daging ayam, daging sapi, telur ayam, dan minyak goreng relatif stabil. Fenomena panic buying yang sempat terjadi di beberapa daerah red zone persebaran Covid-19 berdampak pada keterbatasan akses kelompok rumah tangga kelas menengah ke bawah yang tidak mampu "menyetok" bahan makanan.

Mencermati kondisi perekonomian Indonesia khususnya sebagai dampak penyebaran COVID-19, Gubernur Bank Indonesia, Perry Warjiyo, menyampaikan perkembangan harga-harga di pasar terkendali dan rendah. Berdasarkan Survei Pemantauan Harga (SPH) yang dilakukan oleh Bank Indonesia dengan 46 Kantor Perwakilan Bank Indonesia di daerah, menunjukan bahwa harga-harga di pasar terkendali dan rendah. Pemantauan harga pada minggu kedua April 2020 menunjukkan inflasi akan berada di sekitar 0,20\% (mtm) atau 2,80\% (yoy). Hal tersebut dipengaruhi oleh beberapa faktor, yaitu :

Koordinasi antara pemerintah pusat dan pemerintah daerah melalui TPI/TPID dalam memastikan terpenuhinya kebutuhan pokok.

Tingkat pertumbuhan ekonomi Indonesia akan lebih rendah dari kemampuan kapasitas produksi nasional sehingga mengalami kesenjangan output yang negatif sehingga tekanan inflasi dari sisi permintaan terkendali.

Dampak dari nilai tukar Rupiah terhadap inflasi rendah.

Terjangkarnya ekspektasi inflasi baik di sisi konsumen dan produsen.

BI akan terus memperkuat koordinasi ini dengan Pemerintah dan OJK untuk memonitor secara cermat dinamika penyebaran COVID-19 dan dampaknya terhadap perekonomian Indonesia dari waktu ke waktu, serta langkah-langkah koordinasi kebijakan lanjutan yang perlu ditempuh untuk menjaga stabilitas makroekonomi dan sistem keuangan, serta menopang pertumbuhan ekonomi Indonesia tetap baik dan berdaya tahan. 


\section{Pemikiran Imam Yahya Bin Umar Tentang Regulasi Harga}

Islam merupakan agama yang menjunjung tinggi kebebasan dalam berekonomi. Sehingga Islam memberikan kebebasan kepada umatnya untuk melakukan inovasi dan kreativitas dalam bermuamalah. Kebebasan ekonomi tersebut juga berarti bahwa harga ditentukan oleh kekuatan pasar, yakni kekuatan penawaran (supply) dan permintaan (demand). Dalam kondisi seperti ini, maka pemerintah dilarang melakukan intervensi terhadap harga. Pada pasal 5 ayat 1 dan 2 UU No. 5 Tahun 1999 mengindikasikan adanya larangan untuk melakukan persekongkolan dalam rangka menetapkan harga di pasar.

Berbicara tentang regulasi harga, tentu kita ingat bahwa pengawasan harga (hisbah) muncul pertama kali pada zaman Rasulullah SAW. Pada masa itu, Rasulullah bertindak sebagai hasib (pengawas) -versi Indonesia, KPPU- (Komisi Pengawas Persaingan Usaha). Kondisi saat itu, masyarakat dihadapkan dalam kondisi harga yang melambung tinggi, sehingga sahabat meminta Rasulullah untuk menurunkan harga. Namun demikian, Rasulullah menolak permintaan sahabat tersebut.

Rasulullah mengatakan bahwa Allah mengakui adanya kelebihan dan kekurangan. Dia-lah pembuat harga berubah dan menjadi harga sebenarnya, saya berdo'a agar Allah tidak membiarkan ketidakadilan seseorang dalam darah atau hak milik. Dalam sebuah hadits dinyatakan:

"Dari Anas, ia berkata: Orang-orang berkata, wahai Rasulullah, harga telah naik, maka tetapkanlah harga untuk kami. Lalu Rasulullah SAW bersabda, sesungguhnya Allah yang menetapkan harga, yang mempersempit, dan yang memperluas, dan aku berharap bertemu dengan Allah sedangkan salah salah seorang dari kalian tidak menuntutku karena kezhaliman dalam darah atau harta."

Dari riwayat tersebut, dapat dipahami bahwa penetapan harga secara eksplisit tidak diperkenankan oleh Rasulullah. Sebab dengan penetapan harga akan memicu ketidakadilan baru. Jika harga ditetapkan jauh lebih tinggi maka konsumen akan dirugikan, sebaliknya jika harga ditetapkan sangat rendah, maka produsen yang akan dirugikan. Bagi penulis, hadits di atas dilatarbelakangi oleh kondisi harga yang dalam perspektif Rasulullah masih bisa dijangkau oleh masyarakat. Selain itu, penetapan harga adalah sesuatu yang sensitif, sebab jika terjadi kesalahan dalam menetapkan harga maka akan melahirkan ketidakadilan (injustice) baru dalam kehidupan masyarakat. Pertanyaan yang muncul kemudian adalah bagaimana jika harga komoditas tidak bisa terjangkau oleh daya beli masyarakat.

Dalam hal ini, jika kenaikan harga di pasar diakibatkan oleh ulah para spekulan, sehingga menyebabkan (ketidakstabilan) instabilitas harga di pasar, pemerintah sebagai institusi formal yang mempunyai tanggung jawab menciptakan kesejahteraan umum, berhak melakukan intervensi harga ketika terjadi suatu aktivitas yang dapat membahayakan bagi kehidupan masyarakat luas dengan melakukan stabilisasi. Dua hal yang membolehkan pemerintah melakukan intervensi terhadap regulasi harga di pasar, yaitu:

a. Para pedagang tidak menjual barang dagangan tertentu (ihtikar/monopoly's rentseeking), padahal masyarakat sangat membutuhkannya, akibat ulah dari sebagian pedagang tersebut, harga di pasar menjadi tidak stabil dan hal tersebut dapat membahayakan kehidupan masyarakat luas dan mencegah terciptanya masyarakat yang sejahtera. Dalam kondisi seperti itu pemerintah dapat melakukan intervensi agar harga barang menjadi normal kembali.

b. Sebagian pedagang melakukan praktek siyasah al-ighraq atau banting harga (dumping). Praktek banting harga dapat menimbulkan persaingan yang tidak sehat serta dapat mengacaukan stabilitas harga di pasar. Dalam kondisi seperti ini pemerintah 
mempunyai otoritas untuk memerintahkan para pedagang tersebut agar menaikkan kembali harga barang sesuai dengan harga yang berlaku di pasar.

Statemen Yahya bin Umar tersebut mengindikasikan bahwa ia termasuk salah seorang ulama yang mendukung liberisasi ekonomi (kebebasan ekonomi), termasuk kebebasan kepemilikan. Sikap Rasulullah yang menolak melakukan penetapan harga melalaui statementnya yang tertuang dalam sebuah hadits riwayat Abu Dawud melalui sanad Anas bin Malik, juga merupakan indikasi awal bahwa ekonomi Islam tidak hanya mengatur tentang kepemilikan pribadi, tetapi juga menghormati dan melindunginya. Tentu saja, kebebasan ekonomi yang dimaksud bukanlah kebebasan mutlak tanpa batas sebagaimana dalam ekonomi konvensional. Kebebasan yang dimaksud di sini adalah suatu kebebasan yang tetap berada dalam koridor syariat Islam.

Kebebasan ekonomi tersebut juga berarti bahwa harga ditentukan oleh kekuatan pasar, yakni kekuatan penawaran (supply) dan permintaan (demand). Sebagaimana teori permintaan dan penawaran. Dalam hukum permintaan (demand) dinyatakan bahwa jika harga turun, maka permintaan akan naik, dan sebaliknya jika harga naik maka permintaan akan turun. Hukum ini, secara eksplisit menyatakan adanya hubungan negatif antara permintaan dengan harga. Sedangkan dalam hukum penawaran (supply) justru menyatakan adanya hubungan yang positif antara jumlah barang yang ditawarkan dengan harga yang dikenakan. Jumlah permintaan dan tingkat harga memiliki sifat hubungan yang erat sebagaimana tersebut dalam statemen di atas.

Hal ini disebabkan oleh dua hal, yaitu pertama, kenaikan harga menyebabkan para pembeli mencari barang lain yang dapat digunakan sebagai pengganti (substitusi) dari barang yang mengalami kenaikan harga tersebut. Sebaliknya, jika harga turun maka orang mengurangi pembelian terhadap barang lain yang sama jenisnya dan menambah pembelian terhadap barang yang mengalami penurunan harga. Kedua, kenaikan harga menyebabkan pendapatan riil para pembeli berkurang. Hal ini memaksa para pembeli untuk mengurangi pembeliannya terhadap berbagai jenis barang, terutama barang yang mengalami kenaikan.

Tetapi, sekali lagi bahwa mekanisme harga harus tunduk kepada kaidah-kaidah Islam. Di antara kaidah-kaidah tersebut adalah pemerintah berhak melakukan intervensi ketika terjadi tindakan kesewenang-wenangan dalam pasar, seperti ihtikar dan siyasah alighraq atau banting harga (dumping) yang dilakukan oleh oknum tertentu, sehingga menimbulkan kemudlaratan bagi masyarakat secara umum. Hal ini sesuai dengan tugas yang diemban pemerintah dalam upaya mewujudkan keadilan sosial di setiap kehidupan masyarakat, termasuk ekonomi. Sesuai dengan kaidah fiqhiyah :

"Tindakan pemimpin terhadap rakyat harus dikaitkan dengan kemaslahatan".

Pernyataan Yahya bin Umar yang melarang praktek banting harga (dumping) bukan dimaksudkan untuk mencegah harga barang menjadi murah. Tetapi, lebih pada suatu upaya untuk mencegah terjadinya dampak negatif terhadap mekanisme pasar dan kehidupan masyarakat secara keseluruhan. Jika harga di pasar turun atau murah karena faktor alami tidaklah menjadi masalah, semisal barang di pasar banyak, maka menurut hukum ekonomi harga barang akan turun. Tetapi jika harga di pasar murah, karena ada rekayasa untuk menguasai harga secara monopoli dan berakibat kepailitan pedagang lain, maka hal tersebut dilarang oleh Islam.

\section{Analisis Harga Dampak Covid-19 Menurut Imam Yahya Bin Umar}

Berdasarkan Pusat Informasi Harga Pangan Strategis Nasional (PIHPS) per 23 Maret 2020, beberapa komoditas bahan pokok mengalami kenaikan harga (rata-rata harga nasional) yang signifikan dalam sebulan terakhir dan kenaikan sejak awal tahun (year to date/ytd) antara lain gula pasir lokal 18,71\% (ytd 31,2\%), gula pasir kualitas premium 
10,68\% (ytd 15,54\%), bawang putih naik 36\% (ytd), bawang merah 5,56\% (ytd 4,57\%), cabai rawit merah $18,11 \%$ (ytd $2,74 \%$ ). Sementara itu, harga kebutuhan pokok lainnya seperti beras, daging ayam, daging sapi, telur ayam, dan minyak goreng relatif stabil.

Fenomena panic buying yang sempat terjadi di beberapa daerah red zone persebaran Covid-19 berdampak pada keterbatasan akses kelompok rumah tangga kelas menengah ke bawah yang tidak mampu "menyetok" bahan makanan. Untuk meredam shock kenaikan permintaan, potensi penimbunan kebutuhan pokok, dan kenaikan hargaharga atau bahkan inflasi yang berujung pada krisis, pemerintah harus segera melakukan sesuatu dengan mengeluarkan solusi kebijakan yang tepat.

Mencermati kondisi perekonomian Indonesia khususnya sebagai dampak penyebaran COVID-19, Gubernur Bank Indonesia, Perry Warjiyo, menyampaikan perkembangan harga-harga di pasar terkendali dan rendah. Berdasarkan Survei Pemantauan Harga (SPH) yang dilakukan oleh Bank Indonesia dengan 46 Kantor Perwakilan Bank Indonesia di daerah, menunjukan bahwa harga-harga di pasar terkendali dan rendah. Pemantauan harga pada minggu kedua April 2020 menunjukkan inflasi akan berada di sekitar $0,20 \%(\mathrm{mtm})$ atau $2,80 \%$ (yoy). Hal tersebut dipengaruhi oleh beberapa faktor, yaitu :

Koordinasi antara pemerintah pusat dan pemerintah daerah melalui TPI/TPID dalam memastikan terpenuhinya kebutuhan pokok.

Tingkat pertumbuhan ekonomi Indonesia akan lebih rendah dari kemampuan kapasitas produksi nasional sehingga mengalami kesenjangan output yang negatif sehingga tekanan inflasi dari sisi permintaan terkendali.

Dampak dari nilai tukar Rupiah terhadap inflasi rendah.

Terjangkarnya ekspektasi inflasi baik di sisi konsumen dan produsen.

Dalam rangka memitigasi dampak COVID-19 pada perekonomian dan mencegah terjadinya kenaikan harga pada kebutuhan pokok atau terjadinya inflasi, Pemerintah telah mengumuman stimulus fiskal jilid I, II, dan III. Stimulus fiskal jilid I dan II ditempuh melalui kebijakan bantuan pangan untuk menopang konsumsi masyarakat bawah dan relaksasi perpajakan untuk mendorong keberlangsungan usaha serta menopang daya beli masyarakat. Melengkapi stimulus fiskal jilid I dan II, Pemerintah mengeluarkan stimulus fiskal jilid III dengan total insentif diprakirakan sebesar 430,4 triliun Rupiah. Stimulus fiskal tersebut difokuskan untuk sektor kesehatan, jaring pengaman sosial, dan dukungan bagi industri. Bank Indonesia mengapresiasi langkah stimulus fiskal Pemerintah dalam meminimalkan dampak COVID-19, yang diprakirakan dapat menopang prospek pertumbuhan ekonomi.

Dari kebijakan yang diambil pemerintah diatas, jika dianalisis berdasarkan pemikiran Imam Yahya Bin Umar adalah sejalan dimana pemerintah atau negara tidak mengintervensi harga di pasar melainkan dengan memberikan stimulus fiskal untuk mencegah terjadinya kenaikan harga ataupun inflasi.

Dalam sebuah hadits yang diriwayatkan:

"Dari Anas, ia berkata: Orangorang berkata, "Wahai Rasulullah, harga telah naik, maka tetapkanlah harga untuk kami." Lalu Rasulullah SAW bersabda, "Sesungguhnya Allah yang menetapkan harga, yang mempersempit, dan yang memperluas, dan aku berharap bertemu dengan Allah sedangkan salah salah seorang dari kalian tidak menuntutku karena kezhaliman dalam darah atau harta."

Kaitannya dengan itu, Yahya bin Umar pun meriwayatkan hadits Nabi yang bersumber dari Ibnu Mawab untuk mengklarifikasi masalah ini. Di mana ketika Nabi diminta untuk menempatkan menahan diri atas harga beliau marah dan mengatakan "pasar (harga pasar) berada di tangan Allah Swt. Dialah yang membuatnya naik dan turun, tetapi pergi dan beritahu mereka (orang-orang menyediakan barang-barang 
mereka) untuk membawa barang-barang mereka ke pasar, tidak menyembunyikan dan menjual seperti yang mereka inginkan. Saya tidak ingin dihakimi karena praktik seperti itu dan saya akan membawa antara kamu." Yahya bin Umar juga mengutip pandangan Malik terhadap narh (menahan diri) dan ia menyatakan setuju dengan dia dan menyatakan bahwa tidak mungkin untuk menempatkan pengawasan terhadap harga. Menurut Yahya bin Umar, apabila pasar berjalan dengan secara normal dan harga terbentuk sesuai dengan kekuatan permintaan dan pasokan, maka tidak boleh ada intervensi dari siapapun, termasuk Negara.

\section{KESIMPULAN}

Dalam rangka memitigasi dampak COVID-19 pada perekonomian dan mencegah terjadinya kenaikan harga pada kebutuhan pokok atau terjadinya inflasi, Pemerintah telah mengumuman stimulus fiskal jilid I, II, dan III. Bank Indonesia mengapresiasi langkah stimulus fiskal Pemerintah dalam meminimalkan dampak COVID-19, yang diprakirakan dapat menopang prospek pertumbuhan ekonomi.

Dari kebijakan yang diambil pemerintah diatas, jika dianalisis berdasarkan pemikiran Imam Yahya Bin Umar adalah sejalan dimana pemerintah atau negara tidak mengintervensi harga di pasar melainkan dengan memberikan stimulus fiskal untuk mencegah terjadinya kenaikan harga ataupun inflasi.

Yahya bin Umar mengutip pandangan Malik terhadap narh (menahan diri) dan ia menyatakan setuju dengan dia dan menyatakan bahwa tidak mungkin untuk menempatkan pengawasan terhadap harga. Menurut Yahya bin Umar, apabila pasar berjalan dengan secara normal dan harga terbentuk sesuai dengan kekuatan permintaan dan pasokan, maka tidak boleh ada intervensi dari siapapun, termasuk Negara.

\section{BIBLIOGRAFI}

Abdul Haris Simal, "Konsep Pemikiran Ekonomi Dan Kebijakan Pasar Perspektif Yahya Bin Umar" Diterbitkan oleh UIN Sunan Gunung Djati Bandung: Tahkim Vol.XIV,No.2, Desember 2018.

al-Andalusi, Abu Zakaria Yahya bin Umar bin Yusuf al-Kanani. Kitab al-Suq, Istanbul: ISAM, 2011.

Jalaluddin Abdur Rahman as-Suyuthi, al-Asybah wa al-Nadhair (Indonesia: Syirkah Nur Asia, $\mathrm{tt}$ )

Kepres No. 75 Tahun 1999 Tentang KPPU

Moh. Subhan, "Relevansi Pemikiran Ekonomi Yahya Bin Umar Dalam Perspektif Ekonomi Modern" Diterbitkan oleh Jurnal Ekonomi Syariah - JES, Volume 1, Nomor 2, Maret 2017

Nur Halimah, "Pemikiran Ekonomi Yahya Bin Umar (213-289 H)" Diterbitkan oleh UIN Sultan Syarif Qasim Tahun 2017

Rif'at al-Audi, Min al-Turats: al-Iqtishadi li al-muslimin, Makkah: Rabithah 'Alam alIslamy, 1985

Sudono Sukirno, "Mikro Ekonomi Teori Pengantar" Jakarta: Raja Grafindo Persada, 2006

Internet

https://covid19.go.id/

https://www.suarasurabaya.net/ekonomibisnis/2020/hasil-kajian-indef-soal-penanganan-

wabah-covid-19-dan-dampak-ekonominya/

https://mu2setya1.blogspot.com/2013/03/ayat-dan-hadist-tentang-ekonomi.html?m=1

http://slamet, wiharto.google.com/2008/10/mekanisme pasar menurut islam/ 
http://yanasatia.wordpress.com/2008/31/teori-harga-dalam-mikro-ekonomi-islam/ https://www.suarasurabaya.net/ekonomibisnis/2020/hasil-kajian-indef-soal-penangananwabah-covid-19-dan-dampak-ekonominya/ https://www.bi.go.id/id/ruang-media/info-terbaru/Pages/Perkembangan-Terkini

Perekonomian-dan-Langkah-BI-dalam-Hadapi-COVID-19-09042020.aspx https://www.bi.go.id/id/ruang-media/info-terbaru/Pages/Tinjauan-Kebijakan-MoneterApril-2020.pdf.aspx

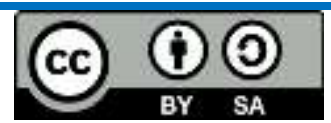

This work is licensed under a Creative Commons Attribution-ShareAlike 4.0 International License 